\title{
Vote, for science!
}

\author{
The US elections take place in a little over a month. How its citizens vote will have a major impact on the scientific \\ community and on the integrity of the scientific enterprise in the United States.
}

W hile the archetype of a scientist is often painted as a lone individual, toiling far from outside influences in the pursuit of truth, the reality is that scientific research is influenced by politics. Scientific research is expensive, and more often than not, the government is helping to foot the bills. Here in the United States (where our editorial team is based), how much money goes to fund research and what lines of research are supported are decisions strongly shaped by the people whom we elect to office.

Once funded, however, scientific research should be free from political interference. Unfortunately, the administration under President Donald Trump has overstepped such boundaries time and again, attempting to interfere with government research projects and bend - or worse, ignore scientists and scientific knowledge to suit its own agenda. The Union of Concerned Scientists has been comprehensively cataloging these breaches; their running list of assaults on science by the Trump administration now contains over 135 entries, including censorship, rollback of public data accessibility, halt or suppression of studies, and sidelining of scientific advisory committees. These attacks on US science must end before irreparable damage is done.

Environmental science and climate change research have been particularly targeted by this administration. In the very first week of the Trump presidency, climate change scientists working at several federal research agencies were banned from speaking to the media. Environmental studies in progress have been halted, language referring to climate change was censored on Department of Energy websites, and Environmental Protection Agency measures put in place to restrict car emissions and to protect sensitive habitats from being exploited for mining operations have been scrapped. At the time of writing, the west coast of the United States is suffering from massive and deadly forest fires, and the Gulf and East coasts have been hard-hit by one of the most active hurricane seasons on record. Yet President Trump continues to question whether climate change plays a role in causing extreme weather conditions.

The administration's visa policies and travel bans have also particularly harmed scientific research in the United States, which critically depends on an influx of foreign-born scientists. Many foreign graduate students and postdocs who come to the United States to study opt to permanently join the US workforce in both academia and industry - some are our own cherished colleagues here at the journal and across Springer Nature. Yet even before pandemic-related travel restrictions were put in place, Trump administration policies were causing distress for foreign scientists and their US-born colleagues. Scientists on visas are afraid to leave the country to visit their families, for fear of not being able to reenter the United States. If such xenophobic policies continue, scientific research in the United States will suffer as young scientists elect to go to countries that are friendlier to immigrants.

Most damning of all, the Trump administration sidelined science when science was needed more than ever, to fight COVID-19. Although all nations have been strained by the pandemic, the United States leads the world in absolute numbers of cases and deaths: at the time of writing, nearly 200,000 people in the country have died. A series of interviews with Trump by journalist Bob Woodward have just come to light, indicating that the President knew just how dangerous this disease is, yet he decided to downplay its seriousness in an attempt to prevent widespread panic. How many of these deaths could have been prevented with a strong, federally coordinated response, informed by scientific knowledge? With immediately forthcoming emergency funding for virus testing and personal protective equipment for frontline workers? With universal, data-driven guidelines for reopening restaurants, stores, offices and schools? With clear, consistent messaging to the public about social distancing and mask-wearing?

The Trump administration has supported the rapid development of a COVID-19 vaccine through its Operation Warp Speed initiative, with multiple vaccines now in clinical trials. But even if and when a safe and effective vaccine is approved, scale-up will take time. The government will also need to wrestle with the problem of vaccine resistance: according to a recent poll, $35 \%$ of people in the United States said they would not get vaccinated. These trials need careful, thorough evaluation to reassure the public, and must not be rushed by politics and the impending election.

President Trump is such a polarizing figure that many of our readers eligible to vote have likely already made up their minds about which candidate will get their vote on November 3. But you, your family members, friends and people in your community might be thinking of sitting this election out. COVID-19 has made physically going to a polling place a health risk. Some people might not trust that their vote-by-mail ballot will actually be counted. Others might even question whether the Postal Service can be trusted to actually deliver it. Reassure your neighbors that their vote matters! Please help get out the vote, for science and for the protection of democracy.

Published online: 29 September 2020 https://doi.org/10.1038/s41592-020-00982-8 